УДК 658.562, 658.588.2

THERMAL CONTROL OF ROLLING BEARINGS AT THE CANNING FACTORY

ТЕПЛОВИЙ КОНТРОЛЬ ПІДШИПНИКІВ КОЧЕННЯ НА КОНСЕРВНОМУ ЗАВОДІ

Peretiaka N. / Перетяка H.O.

Ph.D., Associate Professor / к.т.н., доиент. ORCID: 0000-0003-3370-2140

State University of Intellectual Technologies and Communications, Odessa, Kovalskaya, 15, 65020

Державний університет інтелектуальних технологій $i$ зв'язку,

Одесса, Ковальська, 15, 65020

\begin{abstract}
The paper considers the problems of thermal passive control of mechanical components. Methods of equipment maintenance at the enterprise are shown. The expedient method of non-destructive testing of rolling bearings of different types used in the technological equipment of the cannery is determined. The measuring devices for carrying out passive thermal control are specified. The main disadvantage of the passive method of thermal control of mechanical components - the duration of measurements. To improve the maintenance system, an energyefficient solution has been identified that allows for operational control of rolling bearings at the beginning of the operation of the equipment according to the heating speed parameter.

Key words: non-destructive testing, passive thermal control method, rolling bearing, technical condition, monitoring, heating rate.
\end{abstract}

\title{
Introduction.
}

The food industry occupies a leading position in meeting the needs of the population [1]. Despite the large volumes of production, at all enterprises of the food industry of Ukraine, operating since the times of the USSR, the coefficient of the suitability of fixed assets is about 50\% [2]. This is due to moral and physical deterioration, as well as insufficient renewal of fixed assets. The solution to the problem of eliminating temporary depreciation of fixed assets is their regular repair and renewal, considering the energy efficiency of the measures taken.

At the enterprises of the agroindustry complex, the systems of maintenance of machines and units provide monitoring of mechanical units by the method of passive thermal non-destructive testing. The main disadvantage of this method is the need for a long time for measurements. This leads to useless use of energy and material losses of the enterprise.

Improving the system of maintenance of machines and units of technological equipment of food enterprises is important because it is associated with safety and reliability of operation and reduction of downtime of technological equipment, which has an impact on the cost of production.

The task to be solved in this scientific work is to determine an effective method of thermal non-destructive testing of rolling bearings, considering modern requirements for the implementation of energy-efficient solutions for measurements at existing agricultural enterprises.

\section{The main text.}

Equipment maintenance is carried out based on the application of one of three techniques that have lacks and advantages. The first technique is reactive, which 
involves the operation of the machine to fail. The second method is a planned and preventive method, which involves corrective action. The third method is preventive, which involves maintenance of the actual condition.

Rolling bearings are the most important components integrated into rotating mechanisms. The technical condition of the bearings and related mechanisms can be monitored during operation or after stopping the machine, depending on the operating mode. The wide choice of ways of control of bearings and the elements of the car connected with them during work is caused by a large number of available modern measuring devices. Maintenance techniques differ significantly depending on the type of production. Important parameters of the technical condition of the rolling bearing are noise, temperature, vibration, oil condition.

Contact (Figure 1 (a)) and non-contact thermometers (Figure 1 (b)) are used to measure the heating temperature of machines. Non-contact thermometers are especially useful in hard-to-reach or high-risk areas. Also, infrared thermal imagers can be used to detect abnormal temperature changes or "hot spots" (Figure 1 (c)). Thermal infrared control can detect potential problems and sources of failure without stopping production.

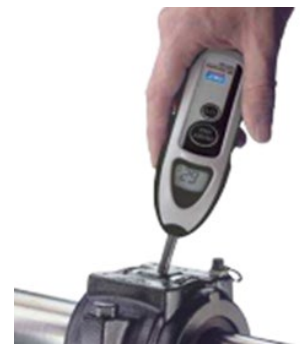

a)

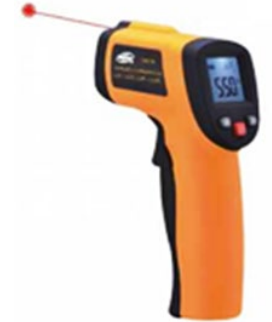

b)

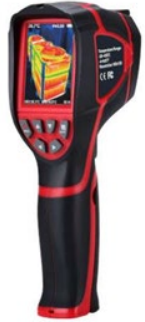

c)

Figure 1 - Measuring instruments for monitoring the operating temperature of bearings

The increase in demand for the thermal method is because any mechanical energy is always accompanied by the release of thermal energy. Thermal field inhomogeneity control is used to assess the technical condition of the object of control. Any deviation of the values of the defining parameters of the current state of the object from the nominal values of the parameters that determine the good condition of the object leads to a change in the temperature field. In practice, the analysis of non-stationary temperature distribution on the surface of the object is carried out on informative grounds. These are local temperature defects or characteristic heat transfer times [3].

The prospect of the thermal method of non-destructive testing is that there is no need to stop the operation of the equipment. Also, the availability of technical equipment and the simplicity of the method of technical control provides acceptable diagnosis reliability of measurements.

At thermal non-destructive testing registration of thermal or temperature fields of the object of control according to requirements of DSTU 2865 is carried out. On the character of interaction of a temperature field with the object of control distinguish methods:

- passive or own radiation; 
- active (the object is affected by an external energy source).

The main advantage of the passive method of thermal control is the efficiency for early detection of bearing damage associated with oil failure, assembly defect and other non-physical damage [4].

Thus, the advantages of using thermal control of rolling bearings in canneries are as follows:

- the ability to identify malfunctions of nascent bearings and non-mechanical damage;

- affordable and inexpensive measuring instruments;

- control by contact or non-contact method;

- a simple method of measurement.

The main disadvantage of the thermal method of assessing the technical condition is the slow response to failure. It takes a long time for the object of control to enter the control mode. Before the instrumental control of the heating temperature of the rolling bearings on the technological equipment of the cannery, it is necessary to operate the equipment for 60 minutes in the nominal mode for the bearing to enter the control mode. With the system of planned and preventive repairs common in the agro-industrial complex, this leads to unnecessary energy costs, which is associated with the operation of equipment without performing production functions. In the system of maintenance and repair of the actual technical condition of the equipment, the extra energy costs are caused by the low efficiency of the equipment in the presence of a defect in the bearing assembly.

In [5], an experimental method for assessing the technical condition of rolling bearings by passive thermal non-destructive testing for an additional diagnostic parameter of the heating rate in the stage of regular heating. It is proposed to assess the efficiency of rolling bearings of technological equipment of canneries according to the criterion "BP". It is experimentally confirmed that the heating rate in the mode of the regular heating mode of the working bearing is

$$
\vartheta_{\mathrm{h}} \leq 1.1^{\circ} \mathrm{C} / \mathrm{min}
$$

This method allows you to solve the problem of inertia of the thermal method by reducing the time of control by 4 times.

\section{Conclusions.}

Methods of technical maintenance of equipment were considered. The most popular method of technical condition of rolling bearings for cannery equipment is the method of passive thermal non-destructive testing. The method allows detecting nascent defects, assembly defects and problems with lubrication without stopping the equipment. Available monitors are used to monitoring rolling bearings by the passive thermal method using a simple method.

The solution to the inertia of the fault response in the passive thermal method of non-destructive testing is to use an additional diagnostic parameter of the heating rate in the stage of regular heating mode according to the criterion "BP". When using such an energy-efficient thermal method, it is possible to determine the technical condition of bearing units at the beginning of work and timely stop the operation of the machine with a malfunctioning bearing or reduce the non-functional use of equipment during preventive repairs. 


\section{References:}

1. Краснолуцька О.В. Аналіз функціонування та тенденцій організаційного розвитку харчової промисловості України. Приазовський економічний вісник. № 3(14). 2019. С. 66-70.

2. Михайленко О. В. Аналіз стану основних засобів підприємств харчової промисловості. Інфраструктура ринку. № 32. 2019. С. 403-407.

3. Вавилов В. П., Торгунаков В.Г., Ширяев В.В., Иванов А.И., Нестерук Д.А. Тепловой неразрушающий контроль в Томском НИИ интроскопии. Известия Томского политехнического университета. 2003. Т.306. №1. С.110118.

4. Moussa W. A Passive Thermography Approach to Bearing Condition Monitoring. JOJ Material Sci. 2017. № 1(4). Pp. 1-7. doi: https://doi.org/10.19080/jojms.2017.01.555567

5. Peretiaka N., Boriak K., Vatrenko O. Improving the thermal method for assessing the technical condition of rolling bearings based on the heating rate criterion. Eastern-European Journal of Enterprise Technologies. №5/1 (107). 2020. P. 118-126. DOI: https://doi.org/10.15587/1729-4061.2020.212540

\section{References.}

1. Krasnolucjka O. V. (2019). Analytyka funkcionuvannja ta tendencij orghanizacijnogho rozvytku kharchovoj promyslovosti Ukrajiny. Pryazovskyj ekonomichnyj visnyk, 3 (14), 66-70.

2. Mykhajlenko O. V. (2019). Analiz stanu osnovnykh zasobiv pidpryjemstv kharchovoji promyslovosti. Ynfrastruktura rynku, 32, 403-407.

3. Vavilov V. P., Torgunakov V.G., Shiryaev V.V., Ivanov A.I., Nesteruk D.A. (2003). Teplovoj nerazrushayushhij kontrol' $\mathrm{v}$ Tomskom NII introskopii. Izvestiya Tomskogo politexnicheskogo universiteta, 306(1), 110-118.

4. Moussa, W. (2017). A Passive Thermography Approach to Bearing Condition Monitoring. Juniper Online Journal Material Science, 1 (4). doi: https://doi.org/10.19080/jojms.2017.01.555567

5. Peretiaka N., Boriak K., Vatrenko O. (2020). Improving the thermal method for assessing the technical condition of rolling bearings based on the heating rate criterion. Eastern-European Journal of Enterprise Technologies, 5/1(107), 118-126. DOI: https://doi.org/10.15587/17294061.2020 .212540

Анотація. В роботі розглядаються проблеми проведення теплового пасивного контролю механічних вузлів. Виділено пріоритети розвитку енергоефективних рімень відновлення основних фондів на підприємствах харчової промисловості. Показані методи технологічного обслуговування обладнання. Визначено, що для контролю підшипників кочення різних типів, які використовують в технологічному обладнанні консервного заводу доиільно застосовувати тепловий пасивний метод неруйнівного контролю. Вказані вимірювальні прилади для проведення пасивного теплового контролю та основні принципи визначення дефектів. Вказані переваги та недоліка теплового методу контролю підшипників. Визначено, що головним недоліком теплового контролю є інериійність відклику несправностей. 3 метою удосконалення системи технічного обслуговування визначено енергоефективне рімення, яке дозволяє проводити оперативний контроль підшипників кочення на початку функиіонування обладнання за параметром швидкості нагріву в режимі регулярного режиму нагріву підшипників.

Ключові слова: неруйнівний контроль, пасивний метод теплового контролю, підшипник кочення, технічний стан, моніторинг, швидкість нагріву. 
The article was prepared in the framework of research work "Improvement of maintenance of machines and units" Article sent: 10.01.2021 (C) Peretiaka N.

Стаття підготовлена в рамках науково-дослідної роботи «Удосконалення системи технічного обслуговування машин та агрегатів» Статья отправлена: 10.01.2021 г. (C) Перетяка Н.O. 